\title{
CAN NO CHILD LEFT BEHIND CLOSE THE GAPS IN PASS RATES ON STANDARDIZED TESTS?
}

\author{
CLAUS M. HOERANDNER and ROBERT J. LEMKE*
}

\begin{abstract}
No Child Left Behind is the most recent federal legislation aimed at eliminating perceived achievement gaps across sociodemographic groups of students in the United States. This article quantifies the degree to which the worst-performing schools can be expected to narrow these gaps by increasing spending to purchase inputs according to better-performing schools. Using data on elementary schools in Illinois, the authors find that 30-50\% of the gap is due to uncontrollable school characteristics, such as the racial composition of students. Characteristics that schools can control, such as hiring more teachers, account for 10-25\% of the gap. (JEL I21, I22, I23)
\end{abstract}

\section{INTRODUCTION}

In a follow-up to the 1966 Coleman report, A Nation at Risk (National Commission on Excellence in Education 1983) documented large and sustaining gaps in student achievement across almost all socioeconomic and demographic groups in the United States. In the continuing struggle to eliminate these gaps, President George W. Bush signed No Child Left Behind (public law 107-110, NCLB) in January 2002. NCLB stipulates that "all students will meet or exceed the state's proficient level of academic achievement" by 2014. Moreover, adequate yearly progress must be demonstrated separately for "economically disadvantaged students, students from major racial and ethnic groups, students with disabilities, and students with limited English proficiency" (pp. 1446-48).

Prior to NCLB's passage, much research discussed the merits and possible pitfalls of high-stakes testing and education accountability systems (Hanushek and Raymond 2001; Ladd 2001; Murnane and Levy 2001).

*The authors thank Dennis Halcoussis, James Hueng, Patrik Hultberg, Bill Sander, Leanna Stiefel, Jeff Sundberg, two referees, and seminar participants at Western Michigan University for valuable comments. The Lake Forest College Department of Economics and Business Faculty-Student Research Fund provided financial assistance.

Hoerandner: Student, Lake Forest College, 555 N. Sheridan Road, Lake Forest, IL 60045. E-mail hoeracm@lakeforest.edu

Lemke: Assistant Professor of Economics, Lake Forest College, 555 N. Sheridan Road, Lake Forest, IL 60045. Phone 1-847-735-5143, Fax 1-847-735-6291, E-maillemke@lakeforest.edu

Contemporary Economic Policy (ISSN 1074-3529)

Vol. 24, No. 1, January 2006, 1-17

Advance Access publication October 19, 2005
Since its passage, NCLB has come under attack from many angles. It is underfunded. The punishments for not "progressing" are quick to be threatened and are overly severe. Standardized tests fail to accurately measure skill levels. It encourages teaching to the test in place of a well-rounded curriculum. States can increase test scores by lowering standards. And so on. ${ }^{1}$ Despite their possible merits, the authors ignore all of these criticisms and accept the goal of having all students achieve a proficient level of academic achievement as measured by their performance on a standardized test.

In this context, therefore, the purpose of this article is to quantify the degree to which the worst-performing schools can realistically increase their pass rates and thereby narrow the gap in pass rates by removing inefficiencies and/or mimicking the education practices of better-performing schools. The authors do this by estimating education

1. Cohn (2000), Kane and Staiger (2002), and Koretz (2002), among others, provide detailed criticisms of NCLB. Linn et al. (2002) discusses the difficulties of defining and demonstrating "annual yearly progress" under NCLB, and Reschovsky and Imazeki (2003) argues that typical state funding procedures do not adequately capture the different financial burdens across districts. In an edited volume by Peterson and West (2003), the political history surrounding NCLB and its potential future struggles and successes are discussed.

\section{ABBREVIATIONS}

ISAT: Illinois Standards Achievement Test NCLB: No Child Left Behind 
production functions, in which average pass rates are the output and school characteristics - some of which schools choose (like class size) and some of which schools cannot choose (like the percent of students from low-income households) - are the inputs. The estimates of the production functions are then used to define the gap in pass rates as the difference between the average pass rate of the worstperforming schools and the average predicted pass rate of better performing schools. The authors then decompose this gap into three parts - the portion due to characteristics that money can buy, the portion due to uncontrollable factors, and the portion due to regression error. Because the regression error accounts for about $40 \%$ of the gap, the interpretation of the regression error will greatly affect policy implications.

Finally, a brief comment on achievement gaps is warranted. First, according to the Coleman report, an achievement gap exists when there is a gap in average academic skills across identifiable groups of students, such as whites and blacks. NCLB considers a different gap. It is concerned not with differences in average levels but with the percent of students who do not demonstrate an acceptable level. If literacy is the standard, for example, then NCLB is concerned with getting all students to be literate rather than ensuring that all groups of students have the same average reading skills. NCLB, therefore, could be successful in eliminating its defined gap of literacy while exacerbating achievement gaps as defined by the Coleman report. In an attempt to evaluate NCLB, therefore, the authors focus on the pass rate of students as defined by those that meet or exceed state standards. Second, the authors do not evaluate the narrowing of pass rates across student demographic groups, which is most appropriately done with student-level data. Rather, the authors are in a better position to simply evaluate the narrowing of pass rates within student demographic groups. Thus the potential effects of NCLB may be much weaker than what is documented because the authors focus solely on closing the gap within subgroups, for example, between Hispanics in the worst and best schools and not, say, between Hispanics in the worst schools and whites in the best schools.

The authors use data on 1,852 elementary schools in Illinois during the 2001-2002 school year that administered state assessments to third graders. The authors find that about $30-50 \%$ of the gap in pass rates across schools is due to uncontrollable school characteristics, such as the economic status or racial composition of the school's students. On the other hand, factors that schools can control, such as lowering class size by hiring more teachers, account for about $10-25 \%$ of the gap in pass rates. Unexplained regression error accounts for the remainder.

Under the best circumstances, education policy will close the gap due to controllable factors and the unexplained regression error. Such a policy, therefore, can reasonably eliminate between $50 \%$ and $70 \%$ of the gap in pass rates across schools. If schools cannot eliminate the unexplained regression error, however, then schools can only be expected to eliminate at most one-fourth of the gap. Unfunded (or underfunded) policies requiring the worst schools to improve to the level of the best schools or even to the level of the average school are likely, therefore, to impose unequal challenges and tax burdens on schools.

The article is organized as follows. The authors discuss the decomposition of the achievement gap in section II and introduce the data in section III. The authors estimate an education production function separately for several groups of students in section IV. Section V uses the production function estimates to decompose the gaps in pass rates for the various groups of students. In section VI, the authors use the decompositions from section $\mathrm{V}$ to discuss the implications of education policies like NCLB that mandate convergence in test scores.

\section{THE EDUCATION PRODUCTION FUNCTION}

The literature on estimating education production functions is large, and for good reason. ${ }^{2}$ Public schooling in the United States is largely locally financed. Thus if the cost of inputs varies across school districts and the degree of substitutability of inputs is limited, then the challenge of educating young

2. See, among others, Bali and Alvarez (2003), Coates (2003), Cook and Evans (2000), Driscoll et al. (2003), Figlio (1999), Goldhaber and Brewer (1997), Hanushek (1986), Hedges and Greenwald (1996), Hoxby (1996), Iatarola and Stiefel (2003), and Krueger (1999). 
people at the local taxpayers' expense will exhibit different opportunities and tradeoffs across school districts. How each school district meets these challenges will depend on local resources and conditions. The results may vary considerably, and undesirable outcomes, such as low test scores, may result in some districts.

The authors estimate education production functions for each socioeconomic and demographic group singled out in NCLB. The regression results are used to calculate and compare expected pass rates for the different demographic groups across schools. The authors then use these estimates to decompose the achievement gap to determine to what extent schools might be able to close these gaps by using their resources more efficiently or by increasing the amount of money they spend. Specifically, the authors assume that two kinds of inputs enter each district's education process - controllable and uncontrollable. The controllable inputs, such as class size, curriculum decisions, and the percent of uncertified teachers to hire, are subject to the school's discretion. Uncontrollable inputs, such as the percent of students who are white or come from low-income households, are, for all practical purposes, out of the control of the school.

Before discussing the details of the decomposition of the production function, the authors must describe the groups of schools over which the decomposition will take place. Consider a population of schools, each with an average pass rate. The authors separate these schools into three groups - the schools with pass rates in the lowest quartile are called Group 1, the schools with pass rates in the inner quartiles are called Group 2, and the schools with pass rates in the highest quartile are called Group 3. The analysis will then focus on decomposing the gap in average pass rates between Group 1 and Groups 2 and 3 .

Let $y$ be a school's average pass rate for a particular demographic group. The production function for each school is assumed to satisfy

$$
y=\beta X+\varepsilon
$$

where $X$ represents all inputs, controllable and uncontrollable, $\beta$ represents the return to each input, and $\varepsilon$ is an error term with standard properties. Using ordinary least squares, the authors obtain a vector of predicted effects, $\hat{\beta}$, that characterize the production of pass rates for the demographic group. The purpose of the decomposition is to explain the difference between Group 1's actual pass rate and Group 2 or 3's predicted pass rate. ${ }^{3}$

To do this, let $\bar{X}_{i}$ and $\bar{y}_{i}$ denote the average input values and the average pass rate for Group $i$, for $i=1,2,3$. Then, by using the regression results, the authors calculate the predicted pass rate for each group, $\hat{\beta} \bar{X}_{i}$. Finally, the authors consider the average predicted pass rate of Group 1 if it purchased the average controllable inputs of Group 2 or 3 . That is, let $\bar{X}_{1,2}$ and $\bar{X}_{1,3}$ denote the vector of Group 1's average uncontrollable characteristics and the average controllable characteristics of Group 2 and Group 3, respectively. The thought experiment is simply that Group 1 schools must keep their uncontrollable characteristics fixed, such as the percent of students from low-income households, but can increase taxes (and spending) to purchase the average level of controllable characteristics of Group 2 or 3. This hypothetical predicted pass rate is $\hat{\beta} \bar{X}_{1,2}$ when Group 1 mimics Group 2 and is $\hat{\beta} \bar{X}_{1,3}$ when Group 1 mimics Group 3.

With these concepts defined, the authors are now ready to present the decomposition. ${ }^{4}$ The authors are interested in explaining the total gap between predicted pass rates of Groups 2 and 3 and the actual pass rates of Group 1:

3. The authors compare actual pass rates of Group 1 to predicted pass rates of Group 2 and 3, because NCLB requires that poorly performing schools (Group 1 schools) improve their actual scores to a general level on par with better-performing schools (Group 2 or 3 schools). Although this level is not stated as a predicted level, it would also not necessarily be the actual level of achievement of the best-performing schools. The results are essentially unchanged if the authors compare actual Group 1 rates to actual Group 2 rates, because the predicted pass rates for Group 2 schools are usually within 1 percentage point of their actual pass rates. If the authors compare actual Group 1 rates to actual Group 3 rates, the percent of the gap that remains unexplained increases substantially for most demographic groups and the percent explained by controllable factors falls by roughly $25 \%$ across all demographic groups. These results are available from the corresponding author on request.

4. The decomposition is similar but not identical to Oaxaca (1973). In particular, the authors do not allow for productivity differences (i.e., different coefficients in the production function) across school groups. The authors impose this restriction because NCLB does not allow schools to appeal to such differences, no matter how real. Reschovsky and Imazeki (2003) argue that such productivity differences exist and that the cost of overcoming these differences can be quite large. In related work, Cook and Evans (2002) decompose an education production function over time. 
$\hat{\beta} \bar{X}_{2}-\bar{y}_{1}$ and $\hat{\beta} \bar{X}_{3}-\bar{y}_{1}$. Each of these can be rewritten as

$$
\begin{aligned}
\hat{\beta} \bar{X}_{2}-\bar{y}_{1}= & \left(\hat{\beta} \bar{X}_{2}-\hat{\beta} \bar{X}_{1,2}\right) \\
& +\left(\hat{\beta} \bar{X}_{1,2}-\hat{\beta} \bar{X}_{1}\right)+\left(\hat{\beta} \bar{X}_{1}-\bar{y}_{1}\right)
\end{aligned}
$$

and

$$
\begin{aligned}
\hat{\beta} \bar{X}_{3}-\bar{y}_{1}= & \left(\hat{\beta} \bar{X}_{3}-\hat{\beta} \bar{X}_{1,3}\right) \\
& +\left(\hat{\beta} \bar{X}_{1,3}-\hat{\beta} \bar{X}_{1}\right)+\left(\hat{\beta} \bar{X}_{1}-\bar{y}_{1}\right)
\end{aligned}
$$

The first term in brackets on the right-hand side is the gap due to uncontrollable characteristics, and hence the authors call this the uncontrollable gap. The middle term is the gap due to differences in the characteristics schools can control. The authors call this the controllable gap. The rightmost term is the gap due to the regression error, called the unexplained gap.

The source of the unexplained gap is important to policy makers. To econometricians, the source of the error is clear-it might be randomness or factors not included in the regression (and, if ordinary least squares is to be unbiased, uncorrelated with the variables included in the regression). From a policy perspective, however, the difference is extremely important. One view is that this gap is due to an inefficient use of resources. ${ }^{5}$ Education policies like NCLB, therefore, might encourage administrators to rid their school of this inefficiency simply by threatening severe sanctions if the gap is not closed. ${ }^{6}$ In short, this approach assumes that the regression error is under the school's control, and legislation like NCLB can make schools act differently to improve test scores. If this is the case, then the rightmost term in brackets in equations (2) and (3) should be viewed as being similar in nature to the middle term as it is controllable at the school level. Another view, however, contends that the unexplained gap captures factors that are out of the school's control, such as luck or family traits. ${ }^{7}$ If this is the case,

5. Efficiency, in this case, is the omitted variable or the source of luck.

6. A school with a low pass rate, however, could still be above its predicted rate. Thus, inefficiency might relate not to pass rates but rather to relative pass rates. Also, there is no explanation as to why some school's pass rates are above expectations. It is difficult to claim, for example, that some schools are inefficient while others are overly efficient.

7. Jaggia and Kelly-Hawke (1999) and Cook and Evans (2000) discuss the possible role of family traits in the education production function. then increased spending in response to legislation calling for schools to be held accountable for student outcomes would at best close the gap due to controllable factors.

The decomposition of actual and predicted pass rates according to equations (2) and (3) will be used to quantify the extent to which increased expenditures and improved efficiency can be expected to increase the pass rates of Group 1. First, the absolute magnitude of the controllable gap and the controllable plus unexplained gap provide estimates of how pass rates might change if the worstperforming schools mimic better schools by purchasing their controllable characteristics. The cost-effectiveness of these improvements can also be measured with an elasticity. The authors assume that purchasing Group 2 or Group 3's average controllable characteristics requires Group 1 to increase local taxes, on average, to the point where they equal average local taxes for Group 2 or Group $3 .^{8}$ Letting $\bar{t}_{i}$ denote average local taxes per student for Group $i$, the elasticity of pass rates with respect to local taxes per student when focusing just on the controllable gap is

$$
\varepsilon_{C}=\frac{\left(\frac{\hat{\beta} \bar{X}_{1, i}-\hat{\beta} \bar{X}_{1}}{\bar{y}_{1}}\right)}{\left(\frac{\bar{t}_{i}-\bar{t}_{1}}{\bar{t}_{1}}\right)}
$$

when comparing Group 1 to Group $i$ for $i=2$ or 3. And the elasticity of pass rates with respect to local taxes per student when focusing on the controllable and unexplained gap is

$$
\varepsilon_{C U}=\frac{\left(\frac{\hat{\beta} \bar{X}_{1, i}-\bar{y}_{1}}{\bar{y}_{1}}\right)}{\left(\frac{\bar{t}_{i}-\bar{t}_{1}}{\bar{t}_{1}}\right)}
$$

when comparing Group 1 to Group $i$ for $i=2$ or 3 .

\section{DATA}

The authors acquired 2001-2002 data on all public elementary schools in Illinois containing a third grade from the Illinois State Board

8. This assumes local spending is not offset from a different revenue source. Card and Payne (2002) find that districts, on average, reduce local tax revenues by about 50 cents for every additional dollar provided by the state. 
of Education. ${ }^{9}$ Illinois administers the Illinois Standards Achievement Test (ISAT) in the third through eighth grades, but the math, English, and writing portions are only administered in grades three, five, and eight. To maintain large sample sizes, focusing on the third grade was preferred because fifth and eighth graders tend to be in middle schools. Additionally, the authors have data on the portion of the curriculum that is devoted to developing math and English skills, but only for the third and eighth grades.

The data considered are exactly those data that districts provide the state to create local report cards as required by NCLB. Thus, one strength of the data is that they not only contain average ISAT scores for the third grade but are broken down by the socioeconomic and demographic groups important to NCLB. That is, in addition to knowing overall average ISAT scores, the authors know the school's average scores separately for its white, black, and Hispanic students, for its nondisabled and disabled students, and for its students from non-low income and low-income households. ${ }^{10}$ It should be noted that the data report the percent of students (within demographic groups) whose ISAT scores fall into one of four categoriesAcademic Warning, Below Standards, Meets Standards, and Exceeds Standards. In each case, the authors simplify the analysis by defining the two highest categories as "passing." Thus, a school's pass rate for a particular demographic group is the percent of its students from that group that meet or exceed state standards.

Because the authors are interested in school test scores, the data used are all collected at the school level except for the amount of local tax revenue per student. The Illinois State Board of Education reports revenue and expenditure data only at the district level. When the authors need a measure of school revenue, therefore, they use the district mill rate multiplied by its average equalized assessed property value scaled to the per pupil level for the entire district. Thus, even though resources may be distributed unequally across schools within a district, every elemen-

9. Links to the data files can be found online at www.isbe.net/research/reports.htm\#statistics.

10. Schools must report their test scores for any subgroup to which more than $5 \%$ of its students belong. tary school in the same district is associated with the same amount of local revenue per student.

Following the previous discussion on education production functions, school characteristics are divided into two groupscontrollable and uncontrollable. The uncontrollable variables that the authors consider are the school's location as measured by being in an inner city or in an urban county, ${ }^{11}$ the percent of its students who are white, black, or Hispanic; school enrollment; the percent of students with limited English proficiency; and the percent of students from low-income households. The controllable factors considered are the school's average class size, the daily attendance rate, the chronic truancy rate, the yearly mobility rate, ${ }^{12}$ the number of minutes devoted to math instruction each day, and the percent of classes taught by uncertified teachers. ${ }^{13}$ With the exception of the attendance, truancy, and mobility rates, the variables lend themselves to be classified as controllable or uncontrollable in a natural way. The reason for categorizing the rate variables as controllable is that the school's atmosphere and environment, which can be controlled in part, affects the students' and parents' view of the school. For example, a school that spends resources to reduce school violence will likely discourage truancy. ${ }^{14}$

Over $20 \%$ of all elementary schools in the state of Illinois are in Chicago. Given their vast overrepresentation and the application to education production functions, the

11. The authors use the U.S. Census Bureau's definition of primary cities to define inner-city schools and its definition of metropolitan statistical areas by county to define urban counties. All inner-city schools, by definition, are located in an urban county.

12. According to the Illinois State Board of Education, "Student mobility reflects any enrollment change between the first school day in October and the last day of the school year. It is the sum of the students who transferred out and the students who transferred in, divided by the average daily enrollment multiplied, by 100 . Students are counted each time they transfer out or in during the reporting year. Thus, individual students may be counted more than once" (www.isbe.net)

13. Teachers are considered to be uncertified ("unqualified" according to Illinois State Board of Education) if they do not hold a teaching license or if they teach in a subject area outside of their formal training.

14. In terms of evaluating how well schools can respond to NCLB, mislabeling factors as being controllable when they are in fact uncontrollable shades the results in favor of NCLB advocates because doing so will overstate the degree to which schools can improve by simply purchasing different "controllable" characteristics. 
TABLE 1

Descriptive Statistics

\begin{tabular}{|c|c|c|c|c|c|c|c|c|c|c|}
\hline & & & & & \multicolumn{6}{|c|}{ Test Score Group } \\
\hline & \multicolumn{4}{|c|}{$\begin{array}{l}\text { All Schools } \\
(N=1,852)\end{array}$} & \multicolumn{2}{|c|}{$\begin{array}{l}\text { Lowest Quartile } \\
\quad(N=463)\end{array}$} & \multicolumn{2}{|c|}{$\begin{array}{l}\text { Inter Quartiles } \\
\quad(N=930)\end{array}$} & \multicolumn{2}{|c|}{$\begin{array}{c}\text { Highest Quartile } \\
\qquad(N=459)\end{array}$} \\
\hline & Mean & SD & Min & Max & Mean & SD & Mean & SD & Mean & SD \\
\hline School is in an inner city & 0.200 & 0.400 & 0 & 1 & 0.294 & 0.456 & 0.165 & 0.371 & 0.184 & 0.388 \\
\hline School is in an urban county & 0.938 & 0.242 & 0 & 1 & 0.948 & 0.223 & 0.915 & 0.279 & 0.977 & 0.149 \\
\hline Percent white students & 70.4 & 29.8 & 0 & 100 & 40.0 & 32.8 & 77.7 & 23.3 & 84.8 & 14.6 \\
\hline Percent black students & 13.6 & 23.2 & 0 & 100 & 35.6 & 33.6 & 7.8 & 13.6 & 4.2 & 8.9 \\
\hline Percent Hispanic students & 12.4 & 20.0 & 0 & 96.9 & 22.6 & 28.4 & 10.8 & 17.2 & 5.8 & 8.5 \\
\hline School enrollment & 484 & 224 & 30 & 1677 & 475 & 236 & 494 & 234 & 472 & 182 \\
\hline $\begin{array}{l}\text { Percent students with limited } \\
\text { English proficiency }\end{array}$ & 6.5 & 12.6 & 0 & 82.7 & 11.4 & 17.8 & 5.5 & 10.8 & 3.7 & 7.4 \\
\hline $\begin{array}{l}\text { Percent students from } \\
\text { low-income households }\end{array}$ & 28.9 & 25.8 & 0 & 100 & 56.2 & 24.2 & 24.6 & 20.4 & 11.0 & 13.8 \\
\hline Average class size & 22.1 & 3.7 & 3 & 35 & 22.2 & 3.9 & 22.1 & 3.7 & 22.0 & 3.6 \\
\hline Average daily attendance rate & 95.4 & 1.1 & 84.4 & 99.2 & 94.6 & 1.4 & 95.5 & 0.9 & 95.9 & 0.7 \\
\hline Average chronic truancy rate & 0.94 & 2.31 & 0 & 32.1 & 2.15 & 3.61 & 0.74 & 1.75 & 0.17 & 0.57 \\
\hline Yearly mobility rate & 16.2 & 11.2 & 0.7 & 106.8 & 24.6 & 13.0 & 15.1 & 9.3 & 10.0 & 7.1 \\
\hline $\begin{array}{l}\text { Minutes devoted to math } \\
\text { each day }\end{array}$ & 57.5 & 10.0 & 25 & 120 & 57.1 & 12.3 & 57.7 & 9.5 & 57.6 & 8.1 \\
\hline $\begin{array}{l}\text { Percent classes taught with } \\
\text { uncertified teachers }\end{array}$ & 0.99 & 5.68 & 0 & 89.7 & 2.47 & 8.44 & 0.73 & 5.23 & 0.08 & 1.04 \\
\hline $\begin{array}{l}\text { Local tax revenue per } \\
\text { student }\end{array}$ & 4,485 & 2,229 & 515 & 18,436 & 3,369 & 1,605 & 4,393 & 2,100 & 5,815 & 2,366 \\
\hline
\end{tabular}

Notes: The data are for all elementary schools in Illinois, except for Chicago public schools, for the 2001-2002 school year. The data are weighted by the approximate number of third graders in each school.

Source: Illinois State Board of Education, 2001-2002 ISAT reports.

Chicago schools were omitted from the analysis. ${ }^{15}$ Table 1 provides the descriptive statistics of the school characteristics for the 1,852 non-Chicago public elementary schools in Illinois. The descriptive statistics are weighted by third-grade enrollment as approximated by each school's enrollment divided by the number of grade levels at the school. Thus, the statistics represent the average third-grade student. Twenty percent of third graders attend an inner-city school, and almost 94\% live in an urban county. Just over $70 \%$ of the students are white, almost $14 \%$ are black, and over $12 \%$ are Hispanic. The average student attends a school that enrolls 484 students. Of all the third graders, $6.5 \%$ are of limited English proficiency and almost 29\% come

15. The results when Chicago public cchools are included are similar to those reported in the article. A full set of results is available from the corresponding author on request. Iatarola and Stiefel (2003) find that the degree to which resources can be distributed unevenly within large school districts can be great. from low-income households. The average student's class has 22 students. The average daily attendance rate is over $95 \%$, and chronic truancy is under $1 \%$. The average student attends a school in which the mobility rate is $16 \%$. The average third grader receives just under an hour of math instruction each day. About $1 \%$ of classes are taught by uncertified teachers, and the average school district collects $\$ 4,485$ of local tax revenue per student.

Although the average characteristics are telling of the non-Chicago students who attended public schools in Illinois in 20012002, there are some extreme outliers to note. Some schools enroll all white or all black students. Total school enrollment can be as low as 30 students and as high as 1,677 students. The range in minutes of math taught each day is also striking, with a low of 25 minutes to a high of 120 minutes. Although some schools do not employ uncertified teachers, other schools teach almost $90 \%$ of their classes with uncertified teachers. Local property taxes range from $\$ 515$ to $\$ 18,436$ per student. 
TABLE 2

Math Pass Rates on the ISAT (and School Counts) by Testing Group

\begin{tabular}{lcccc}
\hline & \multicolumn{3}{c}{ Test Groups } \\
\cline { 2 - 5 } Socio-Demographic Group: & Lowest Quartile & Middle Quartiles & Highest Quartile & Total \\
\hline All students & $60.25 \%(463)$ & $85.05 \%(930)$ & $96.12 \%(459)$ & $81.75 \%(1,852)$ \\
White & $70.78 \%(358)$ & $87.26 \%(904)$ & $96.59 \%(449)$ & $86.32 \%(1,711)$ \\
Black & $47.23 \%(316)$ & $67.11 \%(259)$ & $85.76 \%(59)$ & $59.84 \%(634)$ \\
Hispanic & $61.06 \%(188)$ & $77.06 \%(272)$ & $89.12 \%(64)$ & $73.39 \%(524)$ \\
Nondisabled & $65.42 \%(462)$ & $89.32 \%(929)$ & $97.80 \%(459)$ & $85.62 \%(1,850)$ \\
Disabled & $31.87 \%(333)$ & $58.71 \%(652)$ & $82.64 \%(277)$ & $57.80 \%(1,262)$ \\
Non-low income & $67.15 \%(419)$ & $87.62 \%(918)$ & $96.54 \%(450)$ & $85.16 \%(1,787)$ \\
Low-income & $53.78 \%(371)$ & $73.65 \%(600)$ & $89.79 \%(167)$ & $69.60 \%(1,138)$ \\
\hline
\end{tabular}

Notes: The data are for all elementary schools in Illinois, except for Chicago public schools, for the 2001-2002 school year. The data are weighted by the approximate number of third graders in each school.

Source: Illinois State Board of Education, 2001-2002 ISAT reports.

As mentioned in the previous section, the authors need to define groups of schools to simulate changes in pass rates in response to changes in expenditures. The authors use each school's overall pass rate in math on the ISAT to organize all 1,852 schools into three groups - the bottom quartile (Group 1), the inner quartiles (Group 2), and the top quartile (Group 3). ${ }^{16}$ Moreover, to match the econometric analysis, these groups are determined by weighting each school by its (approximate) third-grade enrollment. In the end, Group 1 contains 463 schools, Group 2 contains 930 schools, and Group 3 contains 459 schools.

Table 1 also contains the mean and standard deviation of each school characteristic for the three groups. The most striking differences are seen in the racial and ethnic composition of students and local taxes. The schools with the lowest pass rates, on average, are less than 50\% white and collect $\$ 3,369$ per student in local taxes. In contrast, schools with the highest pass rates are almost $85 \%$ white and collect $\$ 5,815$ per student in local taxes on average.

Table 2 shows the average pass rates for each student and test group. The average pass rate for all ISAT takers is just over $60 \%$ for Group 1, 85\% for Group 2, and over 96\% for Group 3. The average pass rate over all schools is almost $82 \%$.

16. The authors focus on math results because math tests are usually considered to be more reliable at testing student skills. Others who focus exclusively on math scores include Aksoy and Link (2000), Goldhaber and Brewer (1997), and Sander (1999). Results for reading and writing tests are contained in the appendix tables without discussion.
For each demographic group, notice that the pass rate monotonically increases from Group 1 to Group 2 to Group 3. Thus, the worst-performing schools for one sociodemographic group tend to also be the worstperforming schools for other demographic groups. The level of the difference in pass rates is also noteworthy. The gaps in achievement described in $A$ Nation at Risk remain and are quite large. Over $86 \%$ of white students in the typical school pass, but less than $60 \%$ of black students and $73 \%$ of Hispanic students pass. Likewise, there are substantial gaps between the average pass rates of the disabled and the nondisabled and between students from low-income and non-low income households. ${ }^{17}$

\section{REGRESSION RESULTS}

For each group of students considered (all, white, black, Hispanic, nondisabled, disabled, non-low income, and low-income), the authors estimate the relationship between average pass rates on the math portion of the ISAT and several school characteristics. ${ }^{18}$ Each regression is weighted by the approximate number of third graders in order to

17. All intergroup differences in the final column of Table 2 are statistically significant at the $1 \%$ level.

18. The results for reading and writing tests are given without discussion in the appendix tables. The results using reading scores closely match the results when using math scores. The variation in writing scores that is explained by controllable factors is much less, however, than the variation explained by controllable factors for math or reading scores. 
account for the heteroskedasticity inherent in using average pass rates as the outcome variable. The coefficient estimates and standard errors are reported in Table $3 .{ }^{19}$

Consider first the results for all students (column 1) in Table 3. Inner-city schools are expected to have a pass rate that is more than 4 percentage points higher than their rural counterparts and more than 1 percentage point higher than students in urban schools. Both differences are statistically significant. Pass rates are expected to fall significantly as the percent of students who are black or Hispanic increases, and pass rates fall as school enrollment increases. A school's pass rate is expected to increase with its population of students with limited English proficiency. ${ }^{20}$ Pass rates also fall substantially as the percent of students from low-income households increases.

Of the controllable characteristics, all but the percent of classes taught by an uncertified teacher havea statistically nonzeroeffect. ${ }^{21} \mathrm{Lar}-$ ger classes, greater absenteeism, and greater mobility are all associated with lower pass rates. Higher attendance rates and devoting more time to teaching math skills are both associated with higher pass rates. ${ }^{22}$

With a few notable exceptions, the relationships between inputs and pass rates are more or less constant in sign, if not magnitude, across student groups. ${ }^{23}$ Inner-city schools

19. The results agree largely with Coates (2003) and Sander (1999), both of whom use Illinois data from the 1990s.

20. This may reflect that the test given to students with limited English proficiency is easier conditional on skill level than the standard test. The positive relationship between the percent of students who are designated as having limited English proficiency and overall pass rates is also consistent with the interpretation that schools "game the system" by assigning marginal students who might be in danger of failing the primary assessment to take a modified assessment. For more discussion on gaming test scores, see Cohn (2000), Figlio and Getzler (2002), Jacob and Levitt (2003a, 2003b), Koretz (2002), and Lemke et al. (2004).

21. Because uncertified teachers are frequently licensed teachers in a different specialty (in this case, possibly late elementary instead of early elementary), it may not be surprising to find no relationship between pass rates and the percent of uncertified teachers teaching classes.

22. Using teacher education levels, Coates (2003) and Goldhaber and Brewer (1997) find a positive relationship between teacher quality and test scores. Results on the effect of class size are varied. See, for example, Angrist and Lavy (1999), Driscoll et al. (2003), Figlio (1999), and Hoxby (2000). Aksoy and Link (2000), Coates (2003), Jacques and Brorsen (2002), and Sander (1999) find a positive relationship between math instruction and test scores.

23. Bali and Alvarez (2003) also found regression estimates to be fairly stable across demographic groups. have higher expected pass rates than suburban schools except when considering the pass rates of blacks and students from low-income households - suburban schools have more than $4.5 \%$ more of their black students and more than $2 \%$ more of their low-income students pass. On the whole, pass rates are negatively related to the size of the black population in the school, but pass rates for whites are positively related to the size of the black population at the one percent level. ${ }^{24}$

\section{DECOMPOSING THE GAP IN PASS RATES}

Using the regression results in Table 3, the authors decompose the gap between actual and expected pass rates. Table 4 contains the results from doing this for each of the eight demographic groups. Consider the results for all students first. Group 1 schools had $60.25 \%$ of their students pass. This is reported in the first column of Table 4 under the heading $\bar{y}_{1}$. Using the estimated coefficients in column (1) of Table 3 (denoted by $\hat{\beta}$ ), the predicted average pass rate of Group 1 schools holding fixed their school characteristics (denoted by $\bar{X}_{1}$ ), $\hat{\beta} \bar{X}_{1}$, is $68.78 \%$.

The difference between $\hat{\beta} \bar{X}_{1}$ and $\bar{y}_{1}$ is the unexplained regression error, or simply the unexplained gap. Notice that the unexplained gap is the same regardless of whether the authors compare Group 1 to Group 2 or 3. The unexplained gap, 8.53 percentage points, is reported beneath the regression prediction of 68.78. The exact source of this error, however, remains in question. The most favorable interpretation for NCLB advocates is that this error is some sort of inefficiency that the school could manage to rid itself of if only it spent time, money, and other resources more wisely. ${ }^{25}$ Under this explanation, supporters of NCLB may fully expect schools to overcome this inefficiency. The regression error, however, may be due to nonmonetary or efficiency factors. For example, the error could reflect the educational support students receive in their home life, which schools cannot control (Cook and Evans 2000; Jaggia and Kelly-Hawke 1999). In this case, NCLB

24. Pass rates for Hispanics are also predicted to increase with the size of the black student population, but this is not a statistically significant finding.

25. Under this interpretation, however, it is unclear how to interpret positive regression errors. 
TABLE 3

Regression Results: ISAT Pass Rates in Math by Sociodemographic Groups on School Characteristics

\begin{tabular}{|c|c|c|c|c|c|c|c|c|}
\hline & All & White & Black & Hispanic & Nondis & Disabled & Non-LI & Low Inc. \\
\hline \multirow[t]{2}{*}{ School is in an inner city } & $1.1242^{\mathrm{c}}$ & $1.8350^{\mathrm{a}}$ & $-4.5982^{\mathrm{b}}$ & 2.4662 & $1.2784^{\mathrm{b}}$ & $3.3186^{\mathrm{b}}$ & $4.1396^{\mathrm{a}}$ & $-2.0950^{\mathrm{c}}$ \\
\hline & 0.6011 & 0.6191 & 1.9362 & 2.1490 & 0.5850 & 1.5808 & 0.6272 & 1.2176 \\
\hline \multirow[t]{2}{*}{ School is in an urban county } & $3.0952^{\mathrm{a}}$ & $2.2997^{\mathrm{b}}$ & $18.1022^{\mathrm{b}}$ & $22.9426^{\mathrm{b}}$ & $2.4596^{\mathrm{b}}$ & $5.8307^{\mathrm{b}}$ & $2.9138^{\mathrm{a}}$ & $3.5042^{\mathrm{c}}$ \\
\hline & 1.0329 & 0.9985 & 7.8285 & 9.0110 & 1.0052 & 2.8763 & 1.0618 & 2.0395 \\
\hline \multirow[t]{2}{*}{ Percent students who are black } & $-0.2065^{\mathrm{a}}$ & $0.0548^{\mathrm{a}}$ & $-0.1225^{\mathrm{a}}$ & 0.0244 & $-0.2288^{\mathrm{a}}$ & $-0.2084^{\mathrm{a}}$ & -0.2252 & $-0.2410^{\mathrm{a}}$ \\
\hline & 0.0146 & 0.0186 & 0.0453 & 0.0586 & 0.0142 & 0.0395 & 0.0155 & 0.0285 \\
\hline \multirow[t]{2}{*}{ Percent students who are Hispanic } & $-0.1767^{\mathrm{a}}$ & $-0.1173^{\mathrm{a}}$ & -0.0227 & -0.0041 & $-0.1830^{\mathrm{a}}$ & $-0.1638^{\mathrm{b}}$ & $-0.1611^{\mathrm{a}}$ & $-0.1532^{\mathrm{a}}$ \\
\hline & 0.0272 & 0.0284 & 0.0885 & 0.0719 & 0.0264 & 0.0723 & 0.0286 & 0.0515 \\
\hline \multirow[t]{2}{*}{ Enrollment } & $-0.0020^{\mathrm{c}}$ & $-0.0027^{\mathrm{b}}$ & 0.0017 & $-0.0055^{\mathrm{c}}$ & $-0.0022^{\mathrm{c}}$ & -0.0018 & -0.0008 & -0.0024 \\
\hline & 0.0012 & 0.0012 & 0.0041 & 0.0032 & 0.0011 & 0.0031 & 0.0012 & 0.0025 \\
\hline \multirow[t]{2}{*}{ Percent limited English proficiency } & $0.0741^{\mathrm{c}}$ & 0.0615 & $-0.2244^{\mathrm{c}}$ & 0.0111 & $0.0764^{\mathrm{c}}$ & 0.0652 & 0.0222 & -0.0248 \\
\hline & 0.0406 & 0.0419 & 0.1311 & 0.0945 & 0.0395 & 0.1084 & 0.0425 & 0.0784 \\
\hline \multirow[t]{2}{*}{$\%$ students from low-income households } & $-0.1855^{\mathrm{a}}$ & $-0.2164^{\mathrm{a}}$ & -0.0147 & $-0.1620^{\mathrm{a}}$ & $-0.1618^{\mathrm{a}}$ & $-0.2971^{\mathrm{a}}$ & $-0.0958^{\mathrm{a}}$ & 0.0107 \\
\hline & 0.0168 & 0.0171 & 0.0517 & 0.0575 & 0.0163 & 0.0449 & 0.0176 & 0.0352 \\
\hline \multirow[t]{2}{*}{ Class size } & $-0.1356^{\mathrm{b}}$ & $-0.1575^{\mathrm{b}}$ & -0.0874 & -0.0247 & $-0.2249^{\mathrm{a}}$ & -0.0364 & $-0.1640^{\mathrm{b}}$ & -0.1312 \\
\hline & 0.0665 & 0.0673 & 0.2269 & 0.2251 & 0.0647 & 0.1851 & 0.0694 & 0.1410 \\
\hline \multirow[t]{2}{*}{ Attendance rate } & $1.1104^{\mathrm{a}}$ & $1.6686^{\mathrm{a}}$ & $1.5776^{\mathrm{b}}$ & $2.0173^{\mathrm{b}}$ & $1.0095^{\mathrm{a}}$ & 1.1564 & $1.2986^{\mathrm{a}}$ & $1.4075^{\mathrm{a}}$ \\
\hline & 0.2552 & 0.2792 & 0.7235 & 0.8644 & 0.2484 & 0.7780 & 0.2843 & 0.5251 \\
\hline \multirow[t]{2}{*}{ Truancy rate } & $-0.4667^{\mathrm{a}}$ & $-0.2580^{\mathrm{c}}$ & $-0.6863^{\mathrm{b}}$ & $-0.9439^{\mathrm{a}}$ & $-0.5045^{\mathrm{a}}$ & -0.0598 & $-0.6232^{\mathrm{a}}$ & -0.3659 \\
\hline & 0.1096 & 0.1414 & 0.2707 & 0.3148 & 0.1067 & 0.3196 & 0.1162 & 0.2256 \\
\hline \multirow[t]{2}{*}{ Mobility rate } & $-0.0575^{\mathrm{b}}$ & $-0.0827^{\mathrm{a}}$ & 0.1012 & 0.0057 & -0.0114 & -0.0954 & $-0.0755^{\mathrm{a}}$ & 0.0129 \\
\hline & 0.0261 & 0.0279 & 0.0705 & 0.0754 & 0.0254 & 0.0702 & 0.0275 & 0.0519 \\
\hline \multirow[t]{2}{*}{ Minutes of math instruction per day } & $0.0429^{\mathrm{c}}$ & $0.1194^{\mathrm{a}}$ & 0.0621 & 0.0054 & $0.0618^{\mathrm{a}}$ & 0.0969 & $0.0938^{\mathrm{a}}$ & $0.0897^{\mathrm{b}}$ \\
\hline & 0.0229 & 0.0236 & 0.0714 & 0.0679 & 0.0223 & 0.0614 & 0.0239 & 0.0446 \\
\hline \multirow[t]{2}{*}{$\%$ class taught by uncertified teachers } & -0.0546 & 0.0179 & -0.1169 & -0.1010 & $-0.0743^{\mathrm{c}}$ & -0.1194 & $-0.1988^{\mathrm{a}}$ & -0.0541 \\
\hline & 0.0413 & 0.0472 & 0.0961 & 0.1182 & 0.0402 & 0.1128 & 0.0432 & 0.0763 \\
\hline \multirow[t]{2}{*}{ Constant } & -14.4948 & -70.0559 & -102.816 & -132.701 & -0.4622 & -48.4611 & -34.5207 & -61.9205 \\
\hline & 24.7380 & 27.0315 & 70.420 & 84.203 & 24.0729 & 75.3568 & 27.5732 & 51.0954 \\
\hline$R^{2}$ & 0.5734 & 0.3717 & 0.1127 & 0.1447 & 0.5692 & 0.2831 & 0.4847 & 0.1902 \\
\hline No. of observations & 1,852 & 1,711 & 634 & 524 & 1,850 & 1,262 & 1,787 & 1,138 \\
\hline
\end{tabular}

Notes: Standard errors are reported beneath the coefficient estimates.

${ }^{\text {a }}$ Statistically significant at the $1 \%$ level.

${ }^{\mathrm{b}}$ Statistically significant at the $5 \%$ level.

${ }^{\mathrm{c}}$ Statistically significant at the $10 \%$ level.

Source: Illinois State Board of Education, 2001-2002 ISAT reports. 
TABLE 4

Decomposition of ISAT Pass Rates in Math by Test Group

\begin{tabular}{|c|c|c|c|c|c|c|c|}
\hline & \multirow[b]{2}{*}{$\bar{y}_{\mathbf{1}}$} & \multicolumn{3}{|c|}{$\begin{array}{c}\text { Comparing the Lowest Quartile to } \\
\text { the Middle Quartiles }\end{array}$} & \multicolumn{3}{|c|}{$\begin{array}{c}\text { Comparing the Lowest Quartile to } \\
\text { the Highest Quartile }\end{array}$} \\
\hline & & $\hat{\boldsymbol{\beta}} \bar{X}_{1}$ & $\hat{\boldsymbol{\beta}} \overline{\boldsymbol{X}}_{1,2}$ & $\hat{\boldsymbol{\beta}} \overline{\boldsymbol{X}}_{\mathbf{2}}$ & $\hat{\beta} \bar{X}_{1}$ & $\hat{\boldsymbol{\beta}} \overline{\boldsymbol{X}}_{1,3}$ & $\hat{\boldsymbol{\beta}} \overline{\boldsymbol{X}}_{\mathbf{3}}$ \\
\hline All & 60.25 & 68.78 & 71.18 & 84.15 & 68.78 & 72.26 & 89.51 \\
\hline Absolute difference & & 8.53 & 2.40 & 12.97 & 8.53 & 3.48 & 17.24 \\
\hline$\%$ gap due to difference & & 35.7 & 10.1 & 54.3 & 29.1 & 11.9 & 58.9 \\
\hline Elasticity of pass rates & & 0.466 & 0.131 & & 0.195 & 0.080 & \\
\hline White & 70.78 & 77.75 & 80.55 & 86.52 & 77.75 & 81.82 & 91.26 \\
\hline Absolute difference & & 6.97 & 2.80 & 5.97 & 6.97 & 4.07 & 9.44 \\
\hline$\%$ gap due to difference & & 44.3 & 17.8 & 37.9 & 34.0 & 19.9 & 46.1 \\
\hline Elasticity of pass rates & & 0.324 & 0.130 & & 0.136 & 0.079 & \\
\hline Black & 47.23 & 57.03 & 58.78 & 64.28 & 57.03 & 59.41 & 67.06 \\
\hline Absolute difference & & 9.79 & 1.75 & 5.50 & 9.79 & 2.38 & 7.65 \\
\hline$\%$ gap due to difference & & 57.5 & 10.3 & 32.3 & 49.4 & 12.0 & 38.6 \\
\hline Elasticity of pass rates & & 0.682 & 0.122 & & 0.286 & 0.069 & \\
\hline Hispanic & 61.06 & 67.32 & 70.70 & 73.94 & 67.32 & 72.12 & 79.08 \\
\hline Absolute difference & & 6.26 & 3.38 & 3.25 & 6.26 & 4.81 & 6.96 \\
\hline$\%$ gap due to difference & & 48.6 & 26.2 & 25.2 & 34.7 & 26.7 & 38.6 \\
\hline Elasticity of pass rates & & 0.337 & 0.182 & & 0.141 & 0.108 & \\
\hline Nondisabled & 65.42 & 73.14 & 75.12 & 88.02 & 73.14 & 75.97 & 92.90 \\
\hline Absolute difference & & 7.73 & 1.98 & 12.90 & 7.73 & 2.83 & 16.93 \\
\hline$\%$ gap due to difference & & 34.2 & 8.7 & 57.1 & 28.1 & 10.3 & 61.6 \\
\hline Elasticity of Pass Rates & & 0.389 & 0.099 & & 0.163 & 0.059 & \\
\hline Disabled & 31.87 & 41.44 & 43.80 & 59.88 & 41.44 & 44.88 & 66.92 \\
\hline Absolute difference & & 9.57 & 2.37 & 16.08 & 9.57 & 3.45 & 22.04 \\
\hline$\%$ gap due to difference & & 34.1 & 8.5 & 57.4 & 27.3 & 9.8 & 62.9 \\
\hline Elasticity of pass rates & & 0.987 & 0.244 & & 0.413 & 0.149 & \\
\hline Non-low income & 67.15 & 73.10 & 76.36 & 86.77 & 73.10 & 77.79 & 91.37 \\
\hline Absolute difference & & 5.95 & 3.26 & 10.41 & 5.95 & 4.69 & 13.57 \\
\hline$\%$ gap due to difference & & 30.3 & 16.6 & 53.1 & 24.6 & 19.4 & 56.0 \\
\hline Elasticity of pass rates & & 0.292 & 0.160 & & 0.122 & 0.096 & \\
\hline Low-income & 53.78 & 62.62 & 64.52 & 72.95 & 62.62 & 65.30 & 75.50 \\
\hline Absolute difference & & 8.84 & 1.90 & 8.43 & 8.84 & 2.68 & 10.20 \\
\hline$\%$ gap due to difference & & 46.1 & 9.9 & 44.0 & 40.7 & 12.3 & 47.0 \\
\hline Elasticity of pass rates & & 0.541 & 0.116 & & 0.226 & 0.069 & \\
\hline
\end{tabular}

Notes: $\bar{y}_{1}$ is the average test score of the lowest performing test group. $\hat{\beta} \bar{X}_{1}$ is the predicted average test score of the lowest performing group. $\hat{\beta} \bar{X}_{1,2}$ and $\hat{\beta} \bar{X}_{1,3}$ are the predicted average test scores of the lowest performing group assuming they have the same average controllable characteristics as the respective test groups being compared. $\hat{\beta} \bar{X}_{2}$ and $\beta \bar{X}_{3}$ are the average predicted test scores of the two test groups being compared. The elasticity of test scores is taken with respect to average local tax expenditures.

Source: Illinois State Board of Education, 2001-2002 ISAT reports.

imposes a great and unequal fiscal challenge on the worst (and frequently the poorest) performing schools. Thus, these schools will either fail to achieve NCLB's goals, or the goals of NCLB will be achieved only by imposing unequal burdens on these schools.

Next, the authors calculate the average predicted pass rate of Group 1 schools assuming they retain their uncontrollable characteristics, such as location and enrollment, but increase their financing and purchase the average level of the controllable characteristics that are associated with Group 2 or 3 . These predictions are denoted by $\hat{\beta} \bar{X}_{1,2}$ and $\hat{\beta} \bar{X}_{1,3}$, respectively. If Group 1 schools are associated with the average levels of the controllable characteristics of Group 2 schools, the regression analysis predicts that $71.18 \%$ of Group 1 students would pass. Their predicted pass rate increases to $72.26 \%$ when a similar 
comparison is made to Group 3. The effect of spending additional funds to replicate the inputs of more successful schools, therefore, is estimated by the difference between the predicted pass rate assuming Group 2 or Group 3's controllable characteristics and Group 1's average predicted pass rate: $\hat{\beta} \bar{X}_{1, i}-\hat{\beta} \bar{X}_{1}$ for $i=$ 2,3 . The absolute benefit of these expenditures is reported beneath the estimate of $\hat{\beta} \bar{X}_{1,2}$ and $\hat{\beta} \bar{X}_{1,3}$ in Table 4 . Thus, predicted pass rates for Group 1 increase by 2.4 percentage points when it is assumed to purchase Group 2's average controllable characteristics. The increase is 3.48 percentage points when purchasing Group 3's characteristics. Finally, the authors calculate predicted pass rates for Group $2\left(\hat{\beta} \bar{X}_{2}\right)$ and Group $3\left(\hat{\beta} \bar{X}_{3}\right)$. The average pass rate for Group 2, for example, is $84.15 \%$. The uncontrollable gap, $\hat{\beta} \bar{X}_{2}-\hat{\beta} \bar{X}_{1,2}$, therefore, represents a difference in pass rates of 12.97 percentage points. ${ }^{26}$

The next row of Table 4 reports the percent of the total gap in pass rates that is attributable to each of these three factorsunexplained regression error, controllable factors, and uncontrollable factors. The last row for each demographic group provides an estimate of the elasticity of pass rates with respect to local property tax revenue. That is, assuming that Group 1 schools purchase Group 2 controllable characteristics by increasing local taxes commensurately, specifically, from an average of $\$ 3,369$ per student to $\$ 4,393$ per student - a $30.4 \%$ increasethe elasticity of the response in pass rates can be calculated. (When Group 1 is compared to Group 3, local taxes must change on average from $\$ 3,369$ to $\$ 5,815$, a $72.6 \%$ increase.) The authors report the elasticities for both the unexplained and controllable gaps. The elasticities associated with the controllable gap, $\varepsilon_{C}$, are reported under the column heading $\hat{\beta} \bar{X}_{1,2}$ and $\hat{\beta} \bar{X}_{1,3}$. These elasticities correspond to the effect of additional spending when it is assumed that additional spending will only close the controllable gap. If additional spending closes both the unexplained and controllable gaps, then the elasticity of pass rates with respect to local tax revenue,

26. If the three rate variables - attendance, truancy, and mobility rate - are omitted from the regression or assumed to be uncontrollable on the part of the school, then very little of the gap in pass rates is explainable with factors under the school's control. A full set of these results is available from the corresponding author on request.
$\varepsilon_{C U}$, is the sum of the two elasticities. When comparing Group 1 to Group 2 schools, for example, the gap of 2.4 percentage points due to differing controllable characteristics represents a 3.98\% increase over Group 1's actual pass rate of $60.25 \%$. Thus, the elasticity is calculated as $\varepsilon_{C}=3.98 \div 30.4=0.131$. If the unexplained gap is also closed due to additional tax revenues, one would calculate this portion of the elasticity by recognizing that the unexplained gap of 8.53 percentage points represents $14.16 \%$ of Group 1's actual pass rate. Thus, the elasticity with regard to the unexplained gap is calculated as $14.16 \div 30.4=$ 0.466 . In this case, the elasticity of pass rates with respect to local tax revenue is then calculated as $\varepsilon_{C U}=0.131+0.466=0.597$.

\section{DISCUSSION}

Is it reasonable to expect schools to be able to eliminate gaps in pass rates on standardized tests by improving efficiency or by modestly increasing spending? The results in Table 4 suggest that it is not likely. The percent of the gap in pass rates attributable to uncontrollable factors, such as the percent of students with limited English proficiency, is consistently large. When considering all third graders, uncontrollable school characteristics account for almost 55\% of the gap between the average school in the lowest quartile and the average school in the inner quartiles. Moreover, these results hold, more or less, for all demographic groups. Uncontrollable characteristics account for about $35 \%$ of the gap in pass rates for blacks and between $25 \%$ and $40 \%$ for Hispanics. The results are even more poignant when considering disabled students or students from low-income households, as roughly $60 \%$ and $45 \%$ of the gap in pass rates is attributable to uncontrollable school characteristics, respectively.

Given large achievement gaps due to differences in uncontrollable factors across schools, it is important to investigate the potential effectiveness of increased spending on reducing the gap in pass rates. The conclusions in this area, however, depend on one's perception of the regression error, that is, the unexplained gap. If spending additional resources or restructuring operations does not close the unexplained gap, then a policy like NCLB can be expected, at best, to close the gap due to 
controllable factors. ${ }^{27}$ Table 4 shows that this gap tends to be much smaller than the unexplained gap or the gap due to uncontrollable factors. The controllable gap is roughly $11 \%$ for blacks, 26 percent for Hispanics, 9\% for disabled students, and $11 \%$ for low-income students. Moreover, spending additional tax revenue to close this gap is extremely inefficient because the elasticity of pass rates with respect to local property taxes is consistently below 0.2 (except for disabled students) when comparing schools with the lowest pass rates to schools with pass rates in the inner quartiles (Group 2) and is under 0.10 when comparing to schools with the highest pass rates (Group 3).

The implications for education policy are immediate. When legislation like NCLB sets a primary goal of requiring convergence in test scores, an overly excessive burden will be placed on the worst-performing schools, which are also the most resource-poor. Even if these schools increase funding to match the level spent by better-performing schools (and further assuming that these additional expenditures can actually purchase the same level of inputs of the other schools, an assumption challenged by Reschovsky and Imazeki 2003), the expectation is that the gap in pass rates would narrow by at most $25 \%$, and possibly much less for disabled and low-income students.

On the other hand, one might contend that spending additional resources or restructuring operations will close the unexplained gap in addition to closing the controllable gap. If so, then a policy like NCLB will be much more successful but would still fall short of eliminating achievement gaps. The unexplained and controllable gaps account for between $50 \%$ and $70 \%$ of the gap in pass rates for black and Hispanic students. They account for about $40 \%$ of the gap for disabled students and about $60 \%$ of the gap for students from low-income households. Assuming that legislation like NCLB can close the unexplained gap by either forcing schools to restructure, use resources more wisely, or spend money at the level of more successful schools, a realistic expectation would be for achievement gaps to be about halved. Moreover, the elasticity of pass rates with respect to local tax revenues is much higher when the extra spending is assumed to also close the unexplained gap. For black students, the total elasticity is about 0.8 when comparing the worst schools to the inner quartile schools. The elasticity is only 0.35 when comparing the worst schools to the best schools. The comparable elasticities for Hispanics are 0.52 and 0.25 . The elasticities for disabled students are the largest at a combined rate of 1.23 (the only elastic measure) and 0.56, whereas the elasticities for lowincome students are 0.66 and 0.295 . Even though most of these combined elasticities are still squarely in the inelastic range, they are roughly three to five times greater when factoring in the unexplained gap compared to when only the controllable gap is removed.

Under either assumption, however, it is unreasonable to expect achievement gaps to close easily or cheaply. Moreover, given the large gap due to uncontrollable characteristics and the extremely low elasticities, education policies that require all schools to converge to the same standards without additional federal or state funding are almost certain to place unequal challenges and tax burdens on localities.
27. Even less will be achieved if additional spending fails to purchase the same level of inputs or if the same level of inputs are not equally productive in the worst schools. See Reschovsky and Imazeki (2003) for a further discussion. 
APPENDIX TABLE A1

Regression Results: ISAT Pass Rates in Reading by Sociodemographic Groups on School Characteristics

\begin{tabular}{|c|c|c|c|c|c|c|c|c|}
\hline & All & White & Black & Hispanic & Nondis & Disabled & Non-LI & Low-Inc. \\
\hline \multirow[t]{2}{*}{ School is in an inner city } & 0.5071 & $1.4550^{\mathrm{b}}$ & $-4.6754^{\mathrm{a}}$ & 1.7376 & 0.7478 & $2.8106^{\mathrm{c}}$ & $3.8906^{\mathrm{a}}$ & $-5.3234^{\mathrm{a}}$ \\
\hline & 0.6357 & 0.6939 & 1.7674 & 2.2343 & 0.6491 & 1.5141 & 0.6781 & 1.2435 \\
\hline \multirow[t]{2}{*}{ School is in an urban county } & $2.9743^{\mathrm{a}}$ & 1.7649 & $12.7390^{\mathrm{c}}$ & $15.3302^{\mathrm{b}}$ & $2.5988^{\mathrm{b}}$ & 3.5988 & $2.3091^{\mathrm{b}}$ & $4.3418^{\mathrm{b}}$ \\
\hline & 1.0924 & 1.1192 & 7.6130 & 9.3135 & 1.1154 & 2.7419 & 1.1476 & 2.0829 \\
\hline \multirow[t]{2}{*}{ Percent students who are black } & $-0.1932^{\mathrm{a}}$ & $0.1346^{\mathrm{a}}$ & $-0.0852^{\mathrm{b}}$ & -0.0484 & $-0.2336^{\mathrm{a}}$ & $-0.0655^{\mathrm{c}}$ & $-0.2138^{\mathrm{a}}$ & $-0.2464^{\mathrm{a}}$ \\
\hline & 0.0155 & 0.0208 & 0.0413 & 0.0607 & 0.0158 & 0.0377 & 0.0168 & 0.0291 \\
\hline \multirow[t]{2}{*}{ Percent students who are Hispanic } & $-0.3254^{\mathrm{a}}$ & $-0.2070^{\mathrm{a}}$ & -0.1184 & -0.0916 & $-0.3368^{\mathrm{a}}$ & $-0.2195^{\mathrm{a}}$ & $-0.2919^{\mathrm{a}}$ & $-0.2747^{\mathrm{a}}$ \\
\hline & 0.0287 & 0.0319 & 0.0807 & 0.0743 & 0.0293 & 0.0692 & 0.0309 & 0.0526 \\
\hline \multirow[t]{2}{*}{ Enrollment } & $-0.0031^{\mathrm{b}}$ & $-0.0039^{\mathrm{a}}$ & 0.0020 & $-0.0074^{\mathrm{b}}$ & $-0.0029^{\mathrm{b}}$ & $-0.0078^{\mathrm{a}}$ & -0.0018 & -0.0033 \\
\hline & 0.0012 & 0.0013 & 0.0037 & 0.0033 & 0.0013 & 0.0030 & 0.0013 & 0.0025 \\
\hline \multirow[t]{2}{*}{ Percent limited English proficiency } & $0.1871^{\mathrm{a}}$ & $0.1487^{\mathrm{a}}$ & -0.0961 & 0.0481 & $0.1728^{\mathrm{a}}$ & $0.2764^{\mathrm{a}}$ & $0.1226^{\mathrm{a}}$ & 0.0009 \\
\hline & 0.0429 & 0.0470 & 0.1195 & 0.0977 & 0.0438 & 0.1044 & 0.0459 & 0.0801 \\
\hline \multirow[t]{2}{*}{$\%$ students from low-income households } & $-0.2127^{\mathrm{a}}$ & $-0.2618^{\mathrm{a}}$ & -0.0059 & $-0.1144^{\mathrm{c}}$ & $-0.1954^{\mathrm{a}}$ & $-0.2920^{\mathrm{a}}$ & $-0.1179^{\mathrm{a}}$ & $0.1388^{\mathrm{a}}$ \\
\hline & 0.0177 & 0.0192 & 0.0472 & 0.0595 & 0.0181 & 0.0435 & 0.0191 & 0.0360 \\
\hline \multirow[t]{2}{*}{ Class size } & -0.1086 & $-0.2013^{\mathrm{a}}$ & -0.1794 & -0.0333 & $-0.2137^{\mathrm{a}}$ & -0.0758 & $-0.1668^{\mathrm{b}}$ & $-0.2866^{\mathrm{b}}$ \\
\hline & 0.0703 & 0.0754 & 0.2072 & 0.2330 & 0.0718 & 0.1773 & 0.0748 & 0.1441 \\
\hline \multirow[t]{2}{*}{ Attendance rate } & $1.7293^{\mathrm{a}}$ & $2.4367^{\mathrm{a}}$ & $1.9959^{\mathrm{a}}$ & $1.6043^{\mathrm{c}}$ & $1.6706^{\mathrm{a}}$ & $1.3451^{\mathrm{c}}$ & $1.7555^{\mathrm{a}}$ & $2.3051^{\mathrm{a}}$ \\
\hline & 0.2699 & 0.3130 & 0.6624 & 0.8959 & 0.2756 & 0.7448 & 0.3076 & 0.5368 \\
\hline \multirow[t]{2}{*}{ Truancy rate } & $-0.3147^{\mathrm{a}}$ & -0.1350 & $-0.5420^{\mathrm{b}}$ & $-0.9159^{\mathrm{a}}$ & $-0.3844^{\mathrm{a}}$ & 0.3013 & $-0.4585^{\mathrm{a}}$ & -0.3388 \\
\hline & 0.1159 & 0.1587 & 0.2472 & 0.3260 & 0.1184 & 0.3054 & 0.1282 & 0.2303 \\
\hline \multirow[t]{2}{*}{ Mobility rate } & $-0.0962^{\mathrm{a}}$ & $-0.1449^{\mathrm{a}}$ & 0.0713 & -0.0091 & $-0.0473^{\mathrm{c}}$ & $-0.1194^{\mathrm{c}}$ & $-0.0795^{\mathrm{b}}$ & -0.0267 \\
\hline & 0.0276 & 0.0313 & 0.0644 & 0.0780 & 0.0282 & 0.0676 & 0.0297 & 0.0530 \\
\hline \multirow[t]{2}{*}{ Minutes of English instruction per day } & -0.0015 & $0.0957^{\mathrm{a}}$ & -0.0667 & 0.0079 & 0.0177 & -0.0015 & 0.0320 & $0.0943^{\mathrm{b}}$ \\
\hline & 0.0243 & 0.0265 & 0.0651 & 0.0706 & 0.0248 & 0.0590 & 0.0258 & 0.0457 \\
\hline \multirow[t]{2}{*}{$\%$ class taught by uncertified teachers } & -0.0295 & 0.0241 & 0.0018 & $-0.2400^{\mathrm{b}}$ & -0.0651 & 0.0154 & $-0.0878^{\mathrm{c}}$ & -0.0457 \\
\hline & 0.0437 & 0.0530 & 0.0876 & 0.1222 & 0.0446 & 0.1079 & 0.0480 & 0.0778 \\
\hline \multirow[t]{2}{*}{ Constant } & -81.261 & -149.804 & -144.443 & -102.551 & -69.127 & -81.414 & -83.485 & -164.215 \\
\hline & 26.162 & 30.303 & 64.483 & 87.246 & 26.711 & 72.149 & 29.839 & 52.240 \\
\hline$R^{2}$ & 0.6211 & 0.4264 & 0.1104 & 0.1558 & 0.6190 & 0.2086 & 0.4957 & 0.1950 \\
\hline No. of observations & 1,852 & 1,710 & 630 & 520 & 1,850 & 1,253 & 1,788 & 1,136 \\
\hline
\end{tabular}

Note: Standard errors are reported beneath the coefficient estimates.

${ }^{a}$ Statistically significant at the $1 \%$ level.

${ }^{b}$ Statistically significant at the $5 \%$ level.

${ }^{\mathrm{c}}$ Statistically significant at the $10 \%$ level.

Source: Illinois State Board of Education, 2001-2002 ISAT reports. 
APPENDIX TABLE A2

\begin{tabular}{|c|c|c|c|c|c|c|c|}
\hline & \multirow[b]{2}{*}{$\bar{y}_{1}$} & \multicolumn{3}{|c|}{$\begin{array}{c}\text { Comparing the Lowest Quartile to } \\
\text { the Middle Quartiles }\end{array}$} & \multicolumn{3}{|c|}{$\begin{array}{c}\text { Comparing the Lowest Quartile to } \\
\text { the Highest Quartile }\end{array}$} \\
\hline & & $\hat{\boldsymbol{\beta}} \bar{X}_{1}$ & $\hat{\boldsymbol{\beta}} \bar{X}_{1,2}$ & $\hat{\boldsymbol{\beta}} \bar{X}_{\mathbf{2}}$ & $\hat{\boldsymbol{\beta}} \bar{X}_{1}$ & $\hat{\boldsymbol{\beta}} \bar{X}_{1,3}$ & $\hat{\boldsymbol{\beta}} \overline{\boldsymbol{X}}_{3}$ \\
\hline All & 46.24 & 53.59 & 56.55 & 72.14 & 53.59 & 58.10 & 78.91 \\
\hline Absolute difference & & 7.35 & 2.97 & 15.59 & 7.35 & 4.51 & 20.81 \\
\hline$\%$ gap due to difference & & 28.4 & 11.4 & 60.2 & 22.5 & 13.8 & 63.7 \\
\hline Elasticity of pass rates & & 0.93 & 0.38 & 1.98 & 0.31 & 0.19 & 0.88 \\
\hline White & 58.46 & 64.63 & 68.37 & 75.07 & 64.63 & 70.36 & 81.21 \\
\hline Absolute difference & & 6.17 & 3.75 & 6.69 & 6.17 & 5.73 & 10.86 \\
\hline$\%$ gap due to difference & & 37.1 & 22.6 & 40.3 & 27.1 & 25.2 & 47.7 \\
\hline Elasticity of pass rates & & 1.22 & 0.74 & 1.33 & 0.37 & 0.35 & 0.66 \\
\hline Black & 34.44 & 41.54 & 43.34 & 48.30 & 41.54 & 44.28 & 51.36 \\
\hline Absolute difference & & 7.09 & 1.80 & 4.96 & 7.09 & 2.75 & 7.07 \\
\hline$\%$ gap due to difference & & 51.2 & 13.0 & 35.8 & 42.0 & 16.2 & 41.8 \\
\hline Elasticity of pass rates & & 1.68 & 0.43 & 1.18 & 0.58 & 0.22 & 0.58 \\
\hline Hispanic & 42.95 & 48.01 & 51.36 & 56.16 & 48.01 & 52.68 & 61.04 \\
\hline Absolute difference & & 5.06 & 3.35 & 4.80 & 5.06 & 4.66 & 8.36 \\
\hline$\%$ gap due to difference & & 38.3 & 25.4 & 36.3 & 28.0 & 25.8 & 46.2 \\
\hline Elasticity of pass rates & & 1.26 & 0.83 & 1.19 & 0.39 & 0.36 & 0.64 \\
\hline Nondisabled & 51.70 & 58.82 & 61.48 & 77.86 & 58.82 & 62.75 & 84.31 \\
\hline Absolute difference & & 7.12 & 2.66 & 16.38 & 7.12 & 3.93 & 21.57 \\
\hline$\%$ gap due to difference & & 27.2 & 10.2 & 62.6 & 21.8 & 12.0 & 66.1 \\
\hline Elasticity of pass rates & & 0.90 & 0.33 & 2.06 & 0.30 & 0.17 & 0.91 \\
\hline Disabled & 17.24 & 21.40 & 23.30 & 35.30 & 21.40 & 24.46 & 41.76 \\
\hline Absolute difference & & 4.16 & 1.89 & 12.00 & 4.16 & 3.05 & 17.30 \\
\hline$\%$ gap due to difference & & 23.1 & 10.5 & 66.5 & 17.0 & 12.4 & 70.6 \\
\hline Elasticity of pass rates & & 0.76 & 0.35 & 2.19 & 0.23 & 0.17 & 0.97 \\
\hline Non-low income & 54.94 & 60.19 & 63.39 & 75.87 & 60.19 & 64.90 & 81.33 \\
\hline Absolute difference & & 5.25 & 3.20 & 12.48 & 5.25 & 4.71 & 16.43 \\
\hline$\%$ gap due to difference & & 25.1 & 15.3 & 59.6 & 19.9 & 17.9 & 62.3 \\
\hline Elasticity of pass rates & & 0.82 & 0.50 & 1.96 & 0.27 & 0.25 & 0.86 \\
\hline Low income & 38.29 & 44.67 & 47.63 & 54.56 & 44.67 & 49.01 & 56.68 \\
\hline Absolute difference & & 6.38 & 2.96 & 6.92 & 6.38 & 4.33 & 7.68 \\
\hline$\%$ gap due to difference & & 39.2 & 18.2 & 42.6 & 34.7 & 23.6 & 41.7 \\
\hline Elasticity of pass rates & & 1.29 & 0.60 & 1.40 & 0.48 & 0.32 & 0.57 \\
\hline
\end{tabular}

Note: See Table 4. 
APPENDIX TABLE A3

Regression Results: ISAT Pass Rates in Writing by Sociodemographic Groups on School Characteristics

\begin{tabular}{|c|c|c|c|c|c|c|c|c|}
\hline & All & White & Black & Hispanic & Nondis & Disabled & Non-LI & Low-Inc. \\
\hline \multirow[t]{2}{*}{ School is in an inner city } & $1.9861^{\mathrm{b}}$ & $3.2797^{\mathrm{a}}$ & $-5.6647^{\mathrm{a}}$ & -1.2839 & $2.0306^{\mathrm{b}}$ & $4.7704^{\mathrm{a}}$ & $4.7452^{\mathrm{a}}$ & -1.4090 \\
\hline & 0.9703 & 1.0642 & 1.9959 & 2.6294 & 1.0028 & 1.7007 & 1.0266 & 1.4670 \\
\hline \multirow[t]{2}{*}{ School is in an urban county } & $3.7694^{\mathrm{b}}$ & 2.5966 & 5.3115 & 10.9208 & $3.6881^{\mathrm{b}}$ & 1.9502 & $3.3796^{\mathrm{c}}$ & 2.3836 \\
\hline & 1.6672 & 1.7163 & 8.0566 & 11.0101 & 1.7232 & 3.0948 & 1.7385 & 2.4728 \\
\hline \multirow[t]{2}{*}{ Percent students who are black } & -0.0376 & $0.1096^{\mathrm{a}}$ & -0.0690 & $0.1245^{\mathrm{c}}$ & $-0.0541^{\mathrm{b}}$ & -0.0563 & $-0.0656^{\mathrm{a}}$ & $-0.0673^{\mathrm{c}}$ \\
\hline & 0.0236 & 0.0320 & 0.0466 & 0.0718 & 0.0244 & 0.0424 & 0.0254 & 0.0344 \\
\hline \multirow[t]{2}{*}{ Percent students who are Hispanic } & $-0.1771^{\mathrm{a}}$ & $-0.1688^{\mathrm{a}}$ & -0.1274 & 0.0414 & $-0.1801^{\mathrm{a}}$ & $-0.1549^{\mathrm{b}}$ & $-0.1408^{\mathrm{a}}$ & $-0.1170^{\mathrm{c}}$ \\
\hline & 0.0438 & 0.0489 & 0.0914 & 0.0879 & 0.0453 & 0.0789 & 0.0468 & 0.0623 \\
\hline \multirow[t]{2}{*}{ Enrollment } & 0.0017 & 0.0017 & -0.0016 & 0.0043 & 0.0021 & -0.0030 & 0.0023 & 0.0035 \\
\hline & 0.0019 & 0.0020 & 0.0042 & 0.0039 & 0.0020 & 0.0033 & 0.0020 & 0.0030 \\
\hline \multirow[t]{2}{*}{ Percent limited English proficiency } & $0.1958^{\mathrm{a}}$ & $0.1984^{\mathrm{a}}$ & 0.0181 & 0.0532 & $0.1820^{\mathrm{a}}$ & $0.2955^{\mathrm{b}}$ & 0.0878 & 0.0553 \\
\hline & 0.0655 & 0.0721 & 0.1351 & 0.1155 & 0.0677 & 0.1185 & 0.0695 & 0.0948 \\
\hline \multirow[t]{2}{*}{$\%$ students from low-income households } & $-0.3222^{\mathrm{a}}$ & $-0.3710^{\mathrm{a}}$ & $-0.1247^{\mathrm{b}}$ & $-0.2749^{\mathrm{a}}$ & $-0.3119^{\mathrm{a}}$ & $-0.3167^{\mathrm{a}}$ & $-0.2614^{\mathrm{a}}$ & $-0.096 b$ \\
\hline & 0.0271 & 0.0294 & 0.0532 & 0.0704 & 0.0280 & 0.0487 & 0.0289 & 0.0425 \\
\hline \multirow[t]{2}{*}{ Class size } & 0.0037 & -0.0261 & 0.0138 & -0.0908 & -0.0542 & -0.0772 & -0.070 & 0.2229 \\
\hline & 0.1073 & 0.1156 & 0.2336 & 0.2757 & 0.1110 & 0.1987 & 0.1132 & 0.1708 \\
\hline \multirow[t]{2}{*}{ Attendance rate } & $1.5548^{\mathrm{a}}$ & $2.2677^{\mathrm{a}}$ & $2.0131^{\mathrm{a}}$ & $2.1263^{\mathrm{b}}$ & $1.5997^{\mathrm{a}}$ & $1.558 \mathrm{c}$ & $1.9537^{\mathrm{a}}$ & $1.8003^{\mathrm{a}}$ \\
\hline & 0.4120 & 0.4801 & 0.7473 & 1.0601 & 0.4258 & 0.8354 & 0.4655 & 0.6350 \\
\hline \multirow[t]{2}{*}{ Truancy rate } & 0.0128 & $-0.5853^{\mathrm{b}}$ & 0.0517 & -0.3745 & -0.0058 & -0.0057 & -0.0829 & -0.2509 \\
\hline & 0.1769 & 0.2434 & 0.2785 & 0.3836 & 0.1829 & 0.3422 & 0.1942 & 0.2727 \\
\hline \multirow[t]{2}{*}{ Mobility rate } & $-0.0869^{\mathrm{b}}$ & -0.0591 & 0.0320 & -0.0968 & -0.0572 & $-0.1604^{\mathrm{b}}$ & $-0.0990^{\mathrm{b}}$ & $0.1154^{\mathrm{c}}$ \\
\hline & 0.0421 & 0.0480 & 0.0727 & 0.0922 & 0.0435 & 0.0759 & 0.0450 & 0.0627 \\
\hline \multirow[t]{2}{*}{ Minutes of English instruction per day } & 0.0328 & $0.0985^{\mathrm{b}}$ & 0.0507 & 0.1093 & 0.0485 & 0.0767 & $0.0677^{\mathrm{c}}$ & $0.1056^{\mathrm{c}}$ \\
\hline & 0.0370 & 0.0406 & 0.0735 & 0.0841 & 0.0383 & 0.0660 & 0.0391 & 0.0542 \\
\hline \multirow[t]{2}{*}{$\%$ class taught by uncertified teachers } & -0.0413 & 0.0359 & -0.0783 & $-0.3315^{\mathrm{b}}$ & -0.0700 & 0.0983 & $-0.1238^{\mathrm{c}}$ & 0.0307 \\
\hline & 0.0667 & 0.0812 & 0.0989 & 0.1444 & 0.0689 & 0.1205 & 0.0726 & 0.0921 \\
\hline \multirow[t]{2}{*}{ Constant } & -80.598 & -149.766 & -140.148 & -157.080 & -80.938 & -104.210 & -117.873 & -132.641 \\
\hline & 39.929 & 46.472 & 72.728 & 103.288 & 41.268 & 80.908 & 45.156 & 61.793 \\
\hline$R^{2}$ & 0.3459 & 0.2999 & 0.1345 & 0.1486 & 0.3288 & 0.1879 & 0.2854 & 0.0806 \\
\hline No. of observations & 1,852 & 1,710 & 631 & 519 & 1,849 & 1,238 & 1,786 & 1,136 \\
\hline
\end{tabular}

Note: Standard errors are reported beneath the coefficient estimates.

${ }^{a}$ Statistically significant at the $1 \%$ level.

${ }^{\mathrm{b}}$ Statistically significant at the $5 \%$ level.

${ }^{\mathrm{c}}$ Statistically significant at the $10 \%$ level.

Source: Illinois State Board of Education, 2001-2002 ISAT reports. 
APPENDIX TABLE A4

Decomposition of ISAT Pass Rates in Writing by Test Group

\begin{tabular}{|c|c|c|c|c|c|c|c|}
\hline & \multirow[b]{2}{*}{$\bar{y}_{1}$} & \multicolumn{3}{|c|}{$\begin{array}{c}\text { Comparing the Lowest Quartile to } \\
\text { the Middle Quartiles }\end{array}$} & \multicolumn{3}{|c|}{$\begin{array}{l}\text { Comparing the Lowest Quartile to } \\
\text { the Highest Quartile }\end{array}$} \\
\hline & & $\hat{\hat{\beta}} \bar{X}_{1}$ & $\hat{\boldsymbol{\beta}} \bar{X}_{1,2}$ & $\hat{\boldsymbol{\beta}} \bar{X}_{2}$ & $\hat{\hat{\beta}} \bar{X}_{1}$ & $\hat{\boldsymbol{\beta}} \overline{\boldsymbol{X}}_{1,3}$ & $\overline{\hat{\boldsymbol{\beta}} \bar{X}_{3}}$ \\
\hline All & 34.49 & 51.91 & 53.67 & 63.14 & 51.91 & 54.67 & 69.39 \\
\hline Absolute difference & & 17.42 & 1.76 & 9.47 & 17.42 & 2.75 & 14.72 \\
\hline$\%$ gap due to difference & & 60.8 & 6.1 & 33.0 & 49.9 & 7.9 & 42.2 \\
\hline Elasticity of pass rates & & 2.00 & 0.20 & 1.09 & 0.69 & 0.11 & 0.58 \\
\hline White & 36.82 & 54.02 & 56.59 & 64.72 & 54.02 & 58.08 & 71.20 \\
\hline Absolute difference & & 17.19 & 2.58 & 8.12 & 17.19 & 4.07 & 13.12 \\
\hline$\%$ gap due to difference & & 61.6 & 9.2 & 29.1 & 50.0 & 11.8 & 38.2 \\
\hline Elasticity of pass rates & & 2.03 & 0.30 & 0.96 & 0.69 & 0.16 & 0.53 \\
\hline Black & 28.81 & 46.27 & 47.60 & 53.33 & 46.27 & 48.21 & 56.63 \\
\hline Absolute difference & & 17.46 & 1.33 & 5.73 & 17.46 & 1.94 & 8.42 \\
\hline$\%$ gap due to difference & & 71.2 & 5.4 & 23.4 & 62.8 & $7.0 \%$ & 30.3 \\
\hline Elasticity of pass rates & & 2.34 & 0.18 & 0.77 & 0.86 & 0.10 & 0.42 \\
\hline Hispanic & 33.67 & 47.26 & 50.07 & 54.88 & 47.26 & 51.71 & 59.62 \\
\hline Absolute difference & & 13.59 & 2.81 & 4.81 & 13.59 & 4.45 & 7.92 \\
\hline$\%$ gap due to difference & & 64.1 & 13.3 & 22.7 & 52.4 & 17.1 & 30.5 \\
\hline Elasticity of pass rates & & 2.11 & 0.44 & 0.75 & 0.72 & 0.24 & 0.42 \\
\hline Nondisabled & 37.99 & 56.02 & 57.66 & 67.22 & 56.02 & 58.54 & 73.35 \\
\hline Absolute difference & & 18.03 & 1.64 & 9.56 & 18.03 & 2.52 & 14.81 \\
\hline$\%$ gap due to difference & & 61.7 & 5.6 & 32.7 & 51.0 & 7.1 & 41.9 \\
\hline Elasticity of pass rates & & 2.03 & 0.18 & 1.08 & 0.70 & 0.10 & 0.58 \\
\hline Disabled & 14.24 & 26.06 & 28.22 & 36.86 & 26.06 & 29.50 & 43.17 \\
\hline Absolute difference & & 11.82 & 2.16 & 8.64 & 11.82 & 3.44 & 13.67 \\
\hline$\%$ gap due to difference & & 52.2 & 9.5 & 38.2 & 40.9 & 11.9 & 47.3 \\
\hline Elasticity of pass rates & & 1.72 & 0.31 & 1.26 & 0.56 & 0.16 & 0.65 \\
\hline Non-low income & 38.35 & 54.84 & 57.13 & 65.45 & 54.84 & 58.41 & 71.37 \\
\hline Absolute difference & & 16.49 & 2.28 & 8.33 & 16.49 & 3.57 & 12.95 \\
\hline$\%$ gap due to difference & & 60.9 & 8.4 & 30.7 & 50.0 & 10.8 & 39.2 \\
\hline Elasticity of pass rates & & 2.00 & 0.28 & 1.01 & 0.69 & 0.15 & 0.54 \\
\hline Low-income & 29.70 & 45.71 & 46.55 & 51.09 & 45.71 & 46.94 & 53.71 \\
\hline Absolute difference & & 16.01 & 0.84 & 4.54 & 16.01 & 1.23 & 6.76 \\
\hline$\%$ gap due to difference & & 74.8 & 3.9 & 21.2 & 66.7 & 5.1 & 28.2 \\
\hline Elasticity of pass rates & & 2.46 & 0.13 & 0.70 & 0.92 & 0.07 & 0.39 \\
\hline
\end{tabular}

Note: See Table 4. 


\section{REFERENCES}

Aksoy, T., and C. R. Link. "A Panel Analysis of Student Mathematics Achievement in the U.S. in the 1990s: Does Increasing the Amount of Time in Learning Activities Affect Math Achievement?." Economics of Education Review, 19(3), 2000, 261-77.

Angrist, J. D., and V. Lavy. "Using Maimonides' Rule to Estimate the Effect of Class Size on Scholastic Achievement." Quarterly Journal of Economics, 114(2), 1999, 533-75.

Bali, V. A., and R. M. Alvarez. "Schools and Educational Outcomes: What Causes the 'Race Gap' in Student Test Scores?" Social Science Quarterly, 84(3), 2003, 485-507.

Card, D., and A. A. Payne. "School Finance Reform, the Distribution of School Spending, and the Distribution of Student Test Scores." Journal of Public Economics, 83(1), 2002, 49-82.

Coates, D. "Education Production Functions Using Instructional Time as an Input." Education Economics, 11(3), 2003, 273-92.

Cohn, E. "Selling Higher Test Scores." American Prospect, October 23, 2000, 29-31.

Coleman, J. Equality of Educational Opportunity. Washington, D.C.: Department of Health, Education and Welfare, 1966.

Cook, M. D., and W. N. Evans. "Families or Schools? Explaining the Convergence in White and Black Academic Performance." Journal of Labor Economics, 18(4), 2000, 729-54.

Driscoll, D., D. Halcoussis, and S. Svorny. "School District Size and School Performance." Economics of Education Review, 22(2), 2003, 193-201.

Figlio, D. N. "Functional Form and the Estimated Effects of School Resources." Economics of Education Review, 18(2), 1999, 241-52.

Figlio, D. N., and L. S. Getzler. "Accountability, Ability, and Disability: Gaming the System." National Bureau of Economic Research, working paper 9307. NBER, Cambridge, Mass., October 2002.

Goldhaber, D. D., and D. J. Brewer. "Why Don't Schools and Teachers Seem to Matter?" Journal of Human Resources, 32(3), 1997, 505-23.

Hanushek, E. A. "The Economics of Schooling: Production and Efficiency in Public Schools." Journal of Economic Literature, 24(3), 1986, 1141-77.

Hanushek, E. A., and M. E. Raymond. "The Confusing World of Educational Accountability." National Tax Journal, 54(2), 2001, 365-84.

Hedges, L. V., and R. Greenwald. "Have Times Changed? The Relation between School Resources and Student Performace," in Does Money Matter?: The Effect of School Resources on Student Achievement and Adult Success, edited by Gary Burtless. Washington, D.C.: Brookings Institution Press, 1996.

Hoxby, C. M. "How Teachers' Unions Affect Education Production." Quarterly Journal of Economics, 111(3), 1996, 671-718.

Hoxby, C. M. "The Effects of Class Size on Student Achievement: New Evidence from Population Variation." Quarterly Journal of Economics, 115(4), 2000, 1239-85.
Iatarola, P., and L. Stiefel. "Intradistrict Equity of Public Education Resources and Performance." Economics of Education Review, 22(1), 2003, 69-78.

Jacob, B. A., and S. D. Levitt. "Rotten Apples: An Investigation of the Prevalence and Predictors of Teacher Cheating." National Bureau of Economic Research, working paper 9413. NBER, Cambridge, Mass., January 2003a.

Jacob, B. A., and S. D. Levitt. "Catching Cheating Teachers: The Results of an Unusual Experiment in Implementing Theory," in Brookings-Wharton Papers on Urban Affairs, edited by William G. Gale and Janet Rothenberg Pack. Washington, D.C.: Brookings Institution, 2003b.

Jacques, C., and B. W. Brorsen. "Relationship between Types of School District Expenditures and Student Performance." Applied Economics Letters, 9(15), 2002, 997-1002.

Jaggia, S., and A. Kelly-Hawke. "An Analysis of the Factors that Influence Student Performance: A Fresh Approach to an Old Debate." Contemporary Economic Policy, 17(2), 1999, 189-98.

Kane, T. J., and D. O. Staiger. "The Promise and the Pitfalls of Using Imprecise School Accountability Measures." Journal of Economic Perspectives, 16(4), 2002, 91-114.

Koretz, D. M. "Limitations in the Use of Achievement Tests as Measures of Educators' Productivity." Journal of Human Resources, 37(4), 2002, 753-77.

Krueger, A. B. "Experimental Estimates of Education Production Functions." Quarterly Journal of Economics, 114(2), 1999, 497-532.

Ladd, H. F. "School-Based Educational Accountability Systems: The Promise and the Pitfalls." National Tax Journal, 54(2), 2001, 385-400.

Lemke, R. J., C. M. Hoerandner, and R. E. McMahon. "Student Assessments, Non-Test-Takers, and School Accountability." Manuscript, Lake Forest College, June 2004.

Linn, R. L., E. L. Baker, and D. W. Betebenner. "Accountability Systems: Implications of Requirements of the No Child Left Behind Act of 2001." Educational Researcher, 31(6), 2002, 3-16.

Murnane, R. J., and F. Levy. "Will Standards-Based Reforms Improve the Education of Students of Color?" National Tax Journal, 54(2), 2001, 401-15.

National Commission on Excellence in Education. $A$ Nation at Risk: The Imperative for Education Reform. Washington, D.C.: Government Printing Office, 1983.

Peterson, P. E., and M. R. West (editors). No Child Left Behind? The Politics and Practice of School Accountability. Washington, D.C.: Brookings Institution, 2003.

Oaxaca, R. L. "Male-Female Wage Differentials in Urban Labor Markets." International Economic Review, 14(3), 1973, 693-709.

Reschovsky, A., and J. Imazeki. "Let No Child Be Left Behind: Determining the Cost of Improving Student Performance.” Public Finance Review, 31(10), 2003, 263-90.

Sander, W. "Endogenous Expenditures and Student Achievement." Economics Letters, 64(2), 1999, 223-31. 